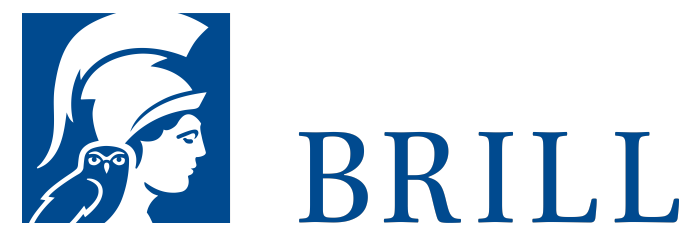

\title{
Amerikas große Ernüchterung
}

Eine Kulturgeschichte der Prohibition

Author: Thomas Welskopp

Seit 1920 war ein nationales Alkoholverbot Bestandteil der amerikanischen Verfassung. Wie konnte es dazu kommen? Wie veränderte die Prohibition die amerikanische Gesellschaft? Welche Gründe führten zu ihrer Abschaffung im Jahre 1933? Thomas Welskopp legt eine Gesamtgeschichte und zugleich umfassende Gesellschaftsgeschichte der Vereinigten Staaten in der Zeit des nationalen Alkoholverbots vor. Ebenso anschaulich wie spannend erzählt der Autor, welch dramatischen Einfluss die Prohibitionsfrage und ihre Behandlung auf fast alle gesellschaftlichen Bereiche der USA ausübte. Wie entwickelten sich das Verfassungsrecht, die illegale - aber auch die legale - Alkoholwirtschaft, die Kultur des Trinkens und die Beziehungen zwischen den Geschlechtern, die Organisierte Kriminalität, die religiösen Milieus, die staatlichen Institutionen, die massenmediale Landschaft und schließlich die politische Kultur mitsamt dem amerikanischen Parteiensystem in den Jahren zwischen der Durchsetzung (1919) und der Abschaffung (1933) der National Prohibition?

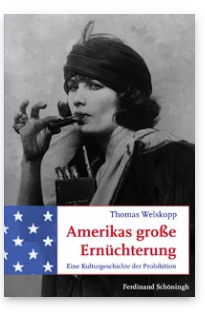

Pages: 700

Seiten, $41 \mathrm{~s} / \mathrm{w}$

Abb.

Language:

German

Subjects:

Modern History, History

Publisher: Brill | Schöningh

E-Book (PDF)

Released online: og Dec 2011

ISBN: 978-3-

657-77026-7

List price

USD $\$ 52.00$

Hardback

Publication date: 15 Sep 2010

ISBN: $978-3^{-}$ 506-77026-4

List price

USD $\$ 52.00$ 
For more information see brill.com

Order information: Order online at brill.com +44330 333 0049 | customerservices@brill.com Submission information: brill.com/authors

Titles published by Brill | Fink, Brill | mentis or Brill | Schöningh: +49(o)715413279216| brill@brocom.de 